\title{
Statistical institutes and economic prosperity
}

\author{
Philip Hans Franses \\ Rianne Legerstee \\ Econometric Institute \\ Erasmus School of Economics
}

Econometric Institute Report 2012-09

\begin{abstract}
The quality of economic institutions can impact economic growth and it can mediate the relation between economic growth and its drivers. We examine the relevance of one such institution, which is the establishment of a national statistical institute for, amongst others, national accounts. We collect data for 106 countries, and we estimate that there are four separate clusters of countries with similar establishment dates. For these clusters we fit regression models to explain economic growth, and we obtain significant differences across these clusters with respect to relevant explanatory variables and effect sizes, suggesting that a national statistics institute indeed is an important institution for the macro-economy.
\end{abstract}

Key words: Institutions; modeling economic growth; statistical institutions JEL codes: E01; E02; E23

This version: May 222012

Address for correspondence is Econometric Institute, Erasmus University Rotterdam, PO Box 1738, NL-3000 DR Rotterdam, The Netherlands, franses@ese.eur.nl 


\section{Introduction}

We propose that the establishment of a national statistical institute is associated with economic prosperity. A statistical institute signals the presence of a "rules of the game" institution, in the terminology of North $(1990,1994)$ and Lin and Nugent (1995), and it reflects societal trust and social coherence ${ }^{1}$. As most statistical institutes are involved in measuring national accounts, an earlier presence of such an institute signals a degree of civilization that might positively be associated with economic growth. Recent news on the functioning of the statistical institute of Greece (see the Appendix for a news article) shows that potential distrust in Greek economic policy might be associated with the less than perfect behavior of the Greece Statistical Institute.

Our argument is based on the analysis of empirical models for growth rates for 106 countries, where we use the establishment dates as an exogenous classifier. As such, our analysis follows a similar strategy as adopted in Cuaresma and Doppelhofer ((2007), Durlauf and Johnson (1995) and Kalaitzidakis et al. (2001), to mention just a few. We create econometric models for growth rates for each of these 106 countries, where we follow the guidelines set out in related studies in which the potentially relevant variables are given, see Barro (1991) and Easterly and Levine (1997), to mention a few. We add to these models a variable that measures the age of a statistical institute, and we find that there is some positive effect on economic growth. More salient results are obtained when we classify the countries according to the ages of the institute using a mixture of normal distributions. We detect 5 clusters of countries, and when we fit separate models for countries within these clusters, we clearly see that there are differences across these models. We take these differences as evidence that the time since establishment of a national statistical institute is an important variable and that the presence of a statistical institute itself is an important institution for a national economy.

Our paper continues with a discussion of the data on the statistical institutes in Section 2. Next, in Section 3, we present the estimation results for a range of models for economic growth. In Section 4 we conclude.

\footnotetext{
${ }^{1}$ A recent excellent survey on various aspects of how institutions and economic performance are related is presented in Ugur (2010). Important alternative views on the relevance of institutions appear in Axelrod (1984) and Williamson (1985). Another interesting survey is Acemoglu et al. (2001).
} 


\section{The establishment of statistical institutes}

We consulted http://www.isi-web.org/statistical-societies/30-statsoc/statsoc/282-nsslist. This website links to the local websites and from there it is possible to retrieve initial starting dates of statistical institutes. For some countries the officially held establishment dates do not correspond with the dates at which a preliminary agency was started, with a focus on compiling national accounts data. For example, the first attempts to start a Statistics Netherlands date back to $1826^{2}$, while the official launch date is currently set at $1899^{3}$. In our analysis we will take the first ever mentioned date as the starting date.

In many cases, the relevant websites are not informative about the establishment date, and in those cases we contacted the offices by e-mail or by phone. Data collection took more than two months, and the end result of our search is presented in Table 1, where we give the establishment dates of national statistical institutes for 106 countries. For all other countries we were not able to retrieve reliable information.

Insert Table 1 about here

The oldest statistical institute is that of Norway (1814), and the most recently founded institute is that of Rwanda (2005). A histogram with the frequencies and years is given in Figure 1.

Insert Figure 1 about here

It is evident from Figure 1 that the distribution of establishment years is far from a symmetric distribution. In fact, it seems that there is more than one distribution, meaning that there could be clusters of years in which a salient number of institutes were founded. For example, the period associated with decolonization in the 60ies and 70ies of last century might have witnessed a substantial number of new national institutes.

\footnotetext{
${ }^{2}$ http://www.cbs.nl/NR/rdonlyres/BD480FBC-24CF-42FA-9A0D-BBECD4F53090/0/200915x10pub.pdf

${ }^{3}$ http://www.cbs.nl/nl-NL/menu/organisatie/geschiedenis/periode-1899-1914-een-vliegende-start.htm
} 
To examine the potential presence of such clusters, we estimate mixtures of $\mathrm{K}$ normal distributions (the EViews code is available upon request from the authors). We set $K$ equal to 3, 4, 5 and 6 (also as visual evidence suggests that $K$ is 2 would be too small), and we compute the values of the information criteria (IC) of Akaike and Schwarz. Table 2 presents these values.

Insert Table 2 about here

The results in Table 2 suggest that Akaike's IC indicates K is 5, while Schwarz's IC suggests $\mathrm{K}$ is 3 . Based on these results, we decide to continue our empirical work with $\mathrm{K}$ is 5 , and when clusters might become too small later on, we will merge the smallest clusters.

Insert Table 3 about here

In Table 3 we present the estimation results for $\mathrm{K}$ is 5 , that is, we present the estimated mean values $\mu_{k}$, where $\mathrm{k}$ runs from 1 to 5 . We find that there are clusters of establishment dates around 1831 (northern and western European countries and the USA), around 1864 (with southern European and also South-American countries), 1914 (like Canada and various Eastern European countries), and the largest two clusters around 1956 and 1980 (many Asian and African countries). In our subsequent empirical analysis, we will consider models for economic growth also for each of the clusters.

\section{Modeling economic growth}

In this section we present the estimation results of various econometric models for economic growth, where we examine if the establishment of a national statistical institute plays any role as related to these models. We consider all 106 countries involved. In the data appendix we outline how we collected the relevant variables and how the variables 
are measured. We follow the current standards in the relevant literature on modeling economic growth and stay as close as possible to the usually used variables.

Our model has as dependent variable the growth rate of real GDP per capita (in current prices), when averaged over the years 1994-2003. We use the acronym “grgdp_1994_2003”. As explanatory variables we use (in random order) the year of origin of a statistical institute (“org_stat”), the (natural) log of government share of current prices GDP, also averaged over 1994-2003 (“gov_share_ln”), the log of openness in current prices, measured as total trade as a percentage of GDP, averaged over 19942003 (“open_share_ln”), the log of the price level of investment, averaged over 19942003 (“price_inv_ln”), the population growth rate, averaged again of the same years (“gr_pop”), the logarithm of real GDP per capita in current prices for 1993 (“gdp_1993”), consumer prices inflation, averaged over 1994-2003 (“infl”), secondary school enrollment for the year 1990 (“sec_school_1990”), and finally the variable with acronym "gastil”, which is an average of a political rights index and a civil liberties index. More details on these variables are given in the data appendix.

In what follows, we will regress economic growth on these variables (in various settings). Next, we delete those variables with $10 \%$ insignificant parameters, and we report estimation results for the final models.

\section{Insert Table 4 about here}

In Table 4 we give the ordinary least squares (OLS) based estimation results for the model with all explanatory variables, except “org_stat”. The fit is a bit above 20\%, and we see that the relevant variables for the full sample (all 106 countries involved) are inflation, population growth and the price of investments, all with a negative effect.

\section{Insert Table 5 about here}

When we add the “org_stat” variable to the basic regression model, we learn from Table 5 that there is a small but positive effect. That is, the older is the statistical institute 
in a country, the larger is economic growth. This result is not very convincing nor subtle, as it aggregates all information into a single variable and a single model.

\section{Insert Table 6 about here}

In Table 6 we do not use the variable "org_stat" but instead we include four dummy variables which are associated with the clusters of Table 3 . When the conditional probability of a year is more than 0.5 , we assign it to a particular cluster of years. This roughly gives the periods before 1990, in between 1900 and 1945, 1946 to 1969, 1970 to 1993 and 1994 and later. When we delete the insignificant terms, we find that the countries with institutes founded in between 1946 and 1969 face higher growth than other countries do.

Our last but most important exercise concerns econometric models for the countries in each of the five clusters. It so turns out that the first cluster (see Table 3, with probability 0.084 ) is too small, so we combine the first two clusters into one. This new cluster contains 29 countries, which have the earliest established statistical institutes.

Insert Table 7 about here

In Table 7 we present the OLS estimation results for this first cluster. Average growth in these countries is $1.87 \%$ per year, and we see that the 1993 GDP level and human rights have a negative effect on economic growth. The last effect is the expected effect, as higher values of this "gastil" variable means less human rights. So, economic growth in civilized countries with early established statistical institutes benefit from more freedom.

Insert Table 8 about here

From Table 8 we learn that, for the countries where the statistical institute was founded in between 1946 and 1969, and with mean growth rates of 3.02\%, economic prosperity mainly benefits from reduced population growth. 
Insert Table 9 about here

Table 9 shows that similar results are obtained for the 40 countries with institutes founded in between 1970 and 1993, where negative population growth is the key factor for economic growth, explaining most of the variance in economic growth.

\section{Insert Table 10 about here}

Finally, Table 10 reports on the estimation results for the remaining 24 countries which share a recently established statistical institute. As expected, these high growth countries can be summarized by a model with most explanatory variables relevant. Except for "gastil", all parameters have the expected sign, and no less than $73 \%$ of the variation in economic growth can be explained by this model. This unexpected sign of "gastil" suggests that democratic virtues are not yet beneficial for developing countries, which is a finding that merits further research.

In sum, when we just add the "org_stat" variable to the model for economic growth, we notice only little effect of the time since the establishment of a statistical institute. However, when we take the foundation dates as a classifier, where we consider four distinct clusters of countries, then we see marked differences across the models for economic growth.

This result tells us that a single model for the 106 countries involved does not make sense, as the statistical relevance of the variables as well as the estimated values of the parameters can be markedly different across the four clusters. It seems that statistical institutes' birth rates are a sensible instrument to divide the data into meaningful groups of countries.

\section{Conclusion}

Our empirical finding in this paper is that the establishment dates of statistical institutes can classify countries in clusters in which models for economic growth have face value, 
in contrast to a single model for all countries. We interpret this finding that such institutes apparently are meaningful economic institutions. 
Table 1: Years in which national statistics institutes were founded

\begin{tabular}{|c|c|c|c|}
\hline Country & Year & Country & Year \\
\hline Albania & 1924 & Estonia & 1990 \\
\hline Algeria & 1971 & Fiji & 1964 \\
\hline Australia & 1905 & Finland & 1865 \\
\hline Austria & 1829 & France & 1833 \\
\hline Bahamas & 1968 & Gambia & 1972 \\
\hline Bahrain & 1967 & Germany & 1872 \\
\hline Bangladesh & 1974 & Greece & 1860 \\
\hline Barbados & 1956 & Hungary & 1867 \\
\hline Belgium & 1826 & Iceland & 1914 \\
\hline Belize & 1964 & India & 1949 \\
\hline Benin & 1954 & Indonesia & 1924 \\
\hline Bolivia & 1863 & Iran & 1956 \\
\hline Botswana & 1967 & Ireland & 1864 \\
\hline Brazil & 1871 & Israel & 1935 \\
\hline Bulgaria & 1880 & Italy & 1861 \\
\hline Burkina Faso & 1958 & Jamaica & 1946 \\
\hline Burundi & 1964 & Japan & 1871 \\
\hline Cambodia & 1979 & Jordan & 1949 \\
\hline Cameroon & 1946 & Kenya & 1961 \\
\hline Canada & 1918 & Korea Republic & 1908 \\
\hline China & 1983 & Kuwait & 1963 \\
\hline Cote d’Ivoire & 1946 & Latvia & 1990 \\
\hline Cyprus & 1960 & Lesotho & 1964 \\
\hline Czech Republic & 1856 & Lithuania & 1990 \\
\hline Denmark & 1850 & Luxembourg & 1900 \\
\hline Ecuador & 1873 & Malaysia & 1949 \\
\hline Egypt & 1905 & Maldives & 1978 \\
\hline
\end{tabular}




\begin{tabular}{|c|c|c|c|}
\hline Malta & 1947 & St. Kitts and Nevis & 1971 \\
\hline Mauritania & 1968 & St. Lucia & 1973 \\
\hline Mauritius & 1945 & St. Vincent and Grenadines & 1983 \\
\hline Mexico & 1980 & Sudan & 1903 \\
\hline Mongolia & 1924 & Suriname & 1947 \\
\hline Namibia & 1994 & Sweden & 1858 \\
\hline Nepal & 1959 & Switzerland & 1860 \\
\hline Netherlands & 1826 & Syria & 1968 \\
\hline Netherlands Antilles & 1976 & Thailand & 1915 \\
\hline Nicaragua & 1939 & Togo & 1956 \\
\hline Niger & 1959 & Tonga & 1975 \\
\hline Nigeria & 1947 & Trinidad and Tobago & 1952 \\
\hline Norway & 1814 & Tunisia & 1969 \\
\hline Oman & 1977 & Turkey & 1918 \\
\hline Pakistan & 1950 & Ukraine & 1991 \\
\hline Panama & 1960 & United Kingdom & 1837 \\
\hline Papua New Guinea & 1981 & United States of America & 1840 \\
\hline Paraguay & 1885 & Uruguay & 1852 \\
\hline Philippines & 1941 & Vanuatu & 1983 \\
\hline Poland & 1918 & Venezuela & 1871 \\
\hline Portugal & 1841 & Vietnam & 1946 \\
\hline Qatar & 1980 & & \\
\hline Romania & 1859 & & \\
\hline Rwanda & 2005 & & \\
\hline Samoa & 1971 & & \\
\hline Saudi Arabia & 1958 & & \\
\hline Sierra Leone & 1961 & & \\
\hline Slovenia & 1829 & & \\
\hline South Africa & 1999 & & \\
\hline Spain & 1856 & & \\
\hline Sri Lanka & 1944 & & \\
\hline
\end{tabular}


Table 2: Model selection criteria for mixtures of K normal distributions

$\mathrm{K}$

3

4

5

6
Akaike IC

10.234

10.253

$\underline{10.198}$

10.210
Bayesian IC

$\underline{10.385}$

10.454

10.450

10.511 
Table 3: Estimation results for mixtures of 5 normal distributions

$\begin{array}{llll}\text { Parameter } & \text { Estimate } & \text { (standard error) } & \text { Probability } \\ \mu_{1} & 1831 & 4.46 & 0.084 \\ \mu_{2} & 1864 & 2.73 & 0.188 \\ \mu_{3} & 1914 & 3.35 & 0.126 \\ \mu_{4} & 1956 & 2.38 & 0.372 \\ \mu_{5} & 1980 & 2.96 & 0.230\end{array}$


Table 4: Regression models for grgdp_1994_2003 for all 106 countries with parameter estimates (estimated standard errors are in parentheses). The variable org_stat is NOT included.

\begin{tabular}{llc} 
Variables & \multicolumn{1}{l}{ Full model } & After deleting insignificant terms \\
Intercept & $8.484(3.578)$ & $7.552(2.129)$ \\
Sec_school_1990 & $0.018(0.012)$ & $-0.015(0.007)$ \\
Infl & $-0.014(0.007)$ & $-0.857(0.174)$ \\
Gr_pop & $-0.929(0.246)$ & \\
GDP_1993_ln & $-0.464(0.357)$ & $-0.958(0.481)$ \\
Price_inv_ln & $-0.770(0.552)$ & \\
Gov_share_ln & $-0.573(0.523)$ & \\
Open_share_ln & $0.552(0.415)$ & \\
Gastil & $0.182(0.150)$ & \\
& & \\
R-squared & 0.265 &
\end{tabular}


Table 5: Regression models for grgdp_1994_2003 for all 106 countries with parameter estimates (estimated standard errors are in parentheses). The variable org_stat is included.

\begin{tabular}{llc} 
Variables & \multicolumn{1}{l}{ Full model } & After deleting insignificant terms \\
Intercept & $-2.979(9.815)$ & $-3.738(8.114)$ \\
Sec_school_1990 & $0.020(0.012)$ & $-0.014(0.007)$ \\
Infl & $-0.013(0.007)$ & $-0.941(0.183)$ \\
Gr_pop & $-0.926(0.245)$ & \\
GDP_1993_ln & $-0.394(0.360)$ & $-0.883(0.481)$ \\
Price_inv_ln & $-0.843(0.554)$ & \\
Gov_share_ln & $-0.785(0.548)$ & \\
Open_share_ln & $0.377(0.437)$ & \\
Gastil & $0.131(0.155)$ & $\mathbf{0 . 0 0 6} \mathbf{( 0 . 0 0 4 )}$ \\
Org_stat & $\mathbf{0 . 0 0 7}(\mathbf{0 . 0 0 5 )}$ & \\
& &
\end{tabular}


Table 6: Regression models for grgdp_1994_2003 for all 106 countries with parameter estimates (estimated standard errors are in parentheses). Dummies for four of the five marked periods are included. The dummy for the countries where the statistical bureau was founded before 1899 is not included and serves as the benchmark.

\begin{tabular}{llll} 
Variables & \multicolumn{1}{l}{ Full model } & After deleting insignificant terms \\
Intercept & $8.229(3.888)$ & $6.578(1.879)$ \\
Sec_school_1990 & $0.019(0.012)$ & \\
Infl & $-0.012(0.007)$ & $-0.014(0.006)$ \\
Gr_pop & $-0.954(0.250)$ & $-0.976(0.191)$ \\
GDP_1993_ln & $-0.399(0.364)$ & $-0.365(0.202)$ \\
Price_inv_ln & $-0.678(0.572)$ & \\
Gov_share_ln & $-0.600(0.548)$ & \\
Open_share_ln & $0.337(0.445)$ & \\
Gastil & 0.124 & $(0.154)$ & \\
Age_stat_dum_1900-1945 & -0.431 & $(0.809)$ & \\
Age_stat_dum_1946_1969 & 1.006 & $(0.903)$ & \\
Age_stat_dum_1970_1993 & 0.579 & $(0.873)$ & \\
Age_stat_dum_1994_2003 & 0.661 & $(0.902)$ & \\
& & & \\
R-squared & 0.299 &
\end{tabular}


Table 7: Regression models for grgdp_1994_2003 for 29 countries (statistical bureau founded before 1945, mean growth is 1.874) with parameter estimates (estimated standard errors are in parentheses).

\begin{tabular}{llcl} 
Variables & \multicolumn{1}{l}{ Full model } & After deleting insignificant terms \\
Intercept & $11.63(10.44)$ & $17.71 \quad(7.076)$ \\
Sec_school_1990 & $0.022(0.025)$ & \\
Infl & $0.008(0.008)$ & \\
Gr_pop & $0.355(0.587)$ & $-1.284(0.671)$ \\
GDP_1993_ln & $-1.640(0.969)$ & \\
Price_inv_ln & $1.024(1.987)$ & \\
Gov_share_ln & $-0.414(1.184)$ & \\
Open_share_ln & $0.862(0.606)$ & $-2.340(0.577)$ \\
Gastil & $-2.181(0.804)$ & \\
& & \\
R-squared & 0.567 &
\end{tabular}


Table 8: Regression models for grgdp_1994_2003 for 13 countries (statistical bureau founded between 1946 and 1969, mean growth is 3.023) with parameter estimates (estimated standard errors are in parentheses).

$\begin{array}{llc}\text { Variables } & \text { Full model } & \text { After deleting insignificant terms } \\ \text { Intercept } & 8.430(20.69) & 5.594(0.982) \\ \text { Sec_school_1990 } & 0.050(0.034) & \\ \text { Infl } & -0.017(0.034) & -1.971(0.666) \\ \text { Gr_pop } & -1.760(1.348) & \\ \text { GDP_1993_ln } & -0.467(1.516) & \\ \text { Price_inv_ln } & -1.096(2.085) & \\ \text { Gov_share_ln } & -1.021(3.070) & \\ \text { Open_share_ln } & 0.771(1.473) & \\ \text { Gastil } & 0.583(0.818) & \\ & & \\ \text { R-squared } & 0.782\end{array}$


Table 9: Regression models for grgdp_1994_2003 for 40 countries (statistical bureau founded between 1970 and 1993, mean growth is 1.867) with parameter estimates (estimated standard errors are in parentheses).

\begin{tabular}{llc} 
Variables & \multicolumn{1}{l}{ Full model } & After deleting insignificant terms \\
Intercept & $3.534(5.605)$ & $3.582(0.664)$ \\
Sec_school_1990 & $-0.001(0.022)$ & $0.060(0.021)$ \\
Infl & $0.069(0.023)$ & $-1.201(0.290)$ \\
Gr_pop & $-0.925(0.352)$ & \\
GDP_1993_ln & $0.188(0.560)$ & \\
Price_inv_ln & $-1.157(0.771)$ & \\
Gov_share_ln & $-0.069(0.719)$ & \\
Open_share_ln & $0.817(0.743)$ & \\
Gastil & $-0.123(0.192)$ & \\
& & \\
R-squared & 0.518 &
\end{tabular}


Table 10: Regression models for grgdp_1994_2003 for 24 countries (statistical bureau founded after 1993, mean growth is 2.346) with parameter estimates (estimated standard errors are in parentheses).

\begin{tabular}{llcl} 
Variables & \multicolumn{1}{l}{ Full model } & After deleting insignificant terms \\
Intercept & $-1.536(6.351)$ & $3.614(4.525)$ \\
Sec_school_1990 & $-0.017(0.019)$ & \\
Infl & $-0.069(0.014)$ & $-0.065(0.013)$ \\
Gr_pop & $-1.687(0.450)$ & $-1.632(0.285)$ \\
GDP_1993_ln & $1.182(0.651)$ & $0.752 \quad(0.405)$ \\
Price_inv_ln & $-2.504(1.055)$ & $-1.893(0.927)$ \\
Gov_share_ln & 1.471 & $(1.195)$ & \\
Open_share_ln & 0.009 & $(0.934)$ & \\
Gastil & 1.167 & $(0.264)$ & $1.025 \quad(0.206)$ \\
& & & 0.730
\end{tabular}




\section{Appendix with news}

\section{Greek statistics}

\section{Numbers in action}

Nov 29th 2011, 17:50 by V.D.

$\bullet$

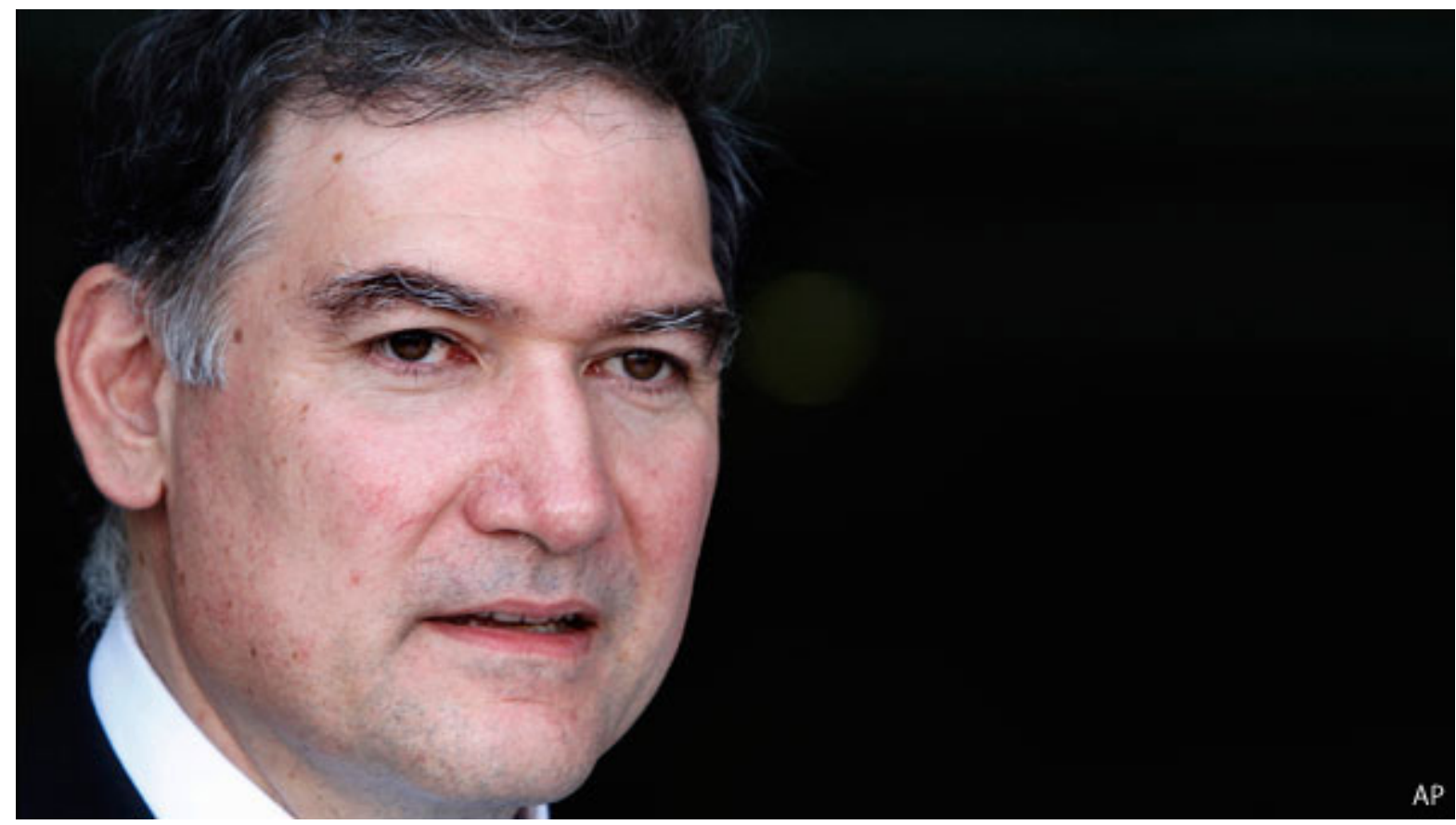

EURO-ZONE finance ministers meeting today in Brussels are preparing to release Greece's latest (and much-delayed) tranche of bail-out funding, worth $€ 8$ billion ( $\$ 10.7$ billion). But all is not well in the country that kicked off the long-running euro crisis. Andreas Georgiou, the head of Elstat, Greece's statistics agency, is facing a criminal investigation for allegedly fiddling the public-finance books.

If the investigation finds that the state was damaged by such actions, Mr Georgiou could be charged with "breach of faith", a crime that carries a potential life sentence. On December 12th he will appear before a prosecutor to provide evidence. He denies the allegation. "Unfortunately, in Greece statistics is a combat sport," he told the Financial Times.

Mr Georgiou stands accused of artificially upping Greece's 2009 budget-deficit figure from $13.4 \%$ to $15.8 \%$ of GDP, taking the country to the top of the euro zone's league of fiscal shame for that year. The revised estimates, say his detractors, 
meant that Greece was forced by its international partners to take ever-harsher austerity measures to receive bail-out funding. Mr Georgiou would make a useful scapegoat to many Greeks who have suffered over the past two years.

The case was brought following claims by Zoi Georganta, an Elstat board member, that Mr Georgiou had inflated the budget-deficit figures. Ms Georganta, along with most of the other board members, was sacked earlier this year. Some former Elstat officials have supported her claims.

Book-cooking is not the only allegation. Nikos Logothetis, Elstat's former vicepresident, has criticised Mr Georgiou for not organising more board meetings and for failing to seek the board's advice on final deficit figures. (Mr Logothetis is also facing criminal charges for hacking into Mr Georgiou's email account; he denies all accusations.)

Before taking up the Elstat job Mr Georgiou was a senior statistician at the IMF for 20 years. In August 2010 he was brought in as head of the new, independent statistical service, which aimed to reassure Greece's international partners concerned about dodgy Greek data. It has largely succeeded in this. Eurostat, the Brussels-based statistics body, has filed no warnings about the reliability of Greek public-finance data under Elstat, which it once did frequently. It has also approved the reviewed 2009 deficit figures.

Greek politicians are contesting Mr Georgiou's numbers, and some would surely be happy to see his head on a plate. But given Elstat's European support, the case seems unlikely to make it past the preliminary hearings. 


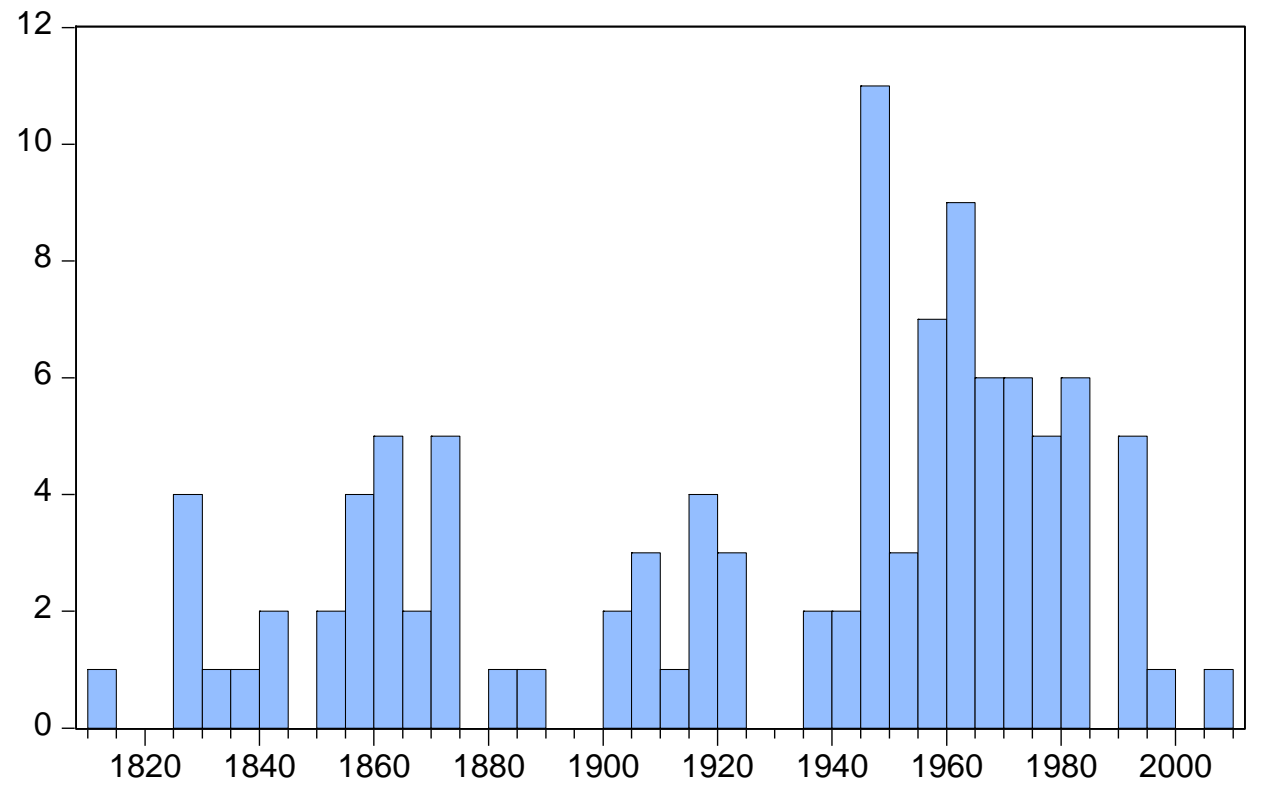

Figure 1: Histogram of establishment years 


\title{
Data Appendix
}

\section{Abbreviations Sources}

\author{
PWT $=$ Penn World Tables \\ WDI $=$ World Development Indicators (The World Bank) \\ GDF = Global Development Finance (The World Bank) \\ GDNGD = Global Development Network Growth Database, uses WDI, GDF and \\ PWT \\ IMF = International Monetary Fund \\ $\mathrm{UN}=$ United Nations \\ UNESCO = United Nations Educational, Scientific and Cultural Organization
}

\section{Series}

\section{Grgdp_1994_2003}

Dependent variable: growth rate of Real GDP per capita (Constant Prices: Chain series) from PWT 6.2. Average value over 1994-2003.

As explained in Summers and Heston (1991) pg 343-344 there are four measures of GDP per capita in the Penn World Tables: real per capita GDP expressed in current international prices (CGDP), real per capita GDP expressed in 2000 international prices using the Laspeyres-method (RGDPL), real per capita GDP expressed in 2000 international prices using the chain-method (RGDPCH) and real per capita GDP expressed in 2000 international prices using the Laspeyres-method adjusted for terms of trade (RGDPTT). In any year, CGDP is directly comparable across countries, but inflation effects keep it from being comparable over time. Both RGDPL and RGDPCH are directly comparable across time and countries, but the first suffers from the Laspeyres fixed-base problem: after a while, relative prices change, and the base year weights become less and less appropriate. A way of mitigating the declining appropriateness of the base year weights for comparison years distant from 2000 is to 
bring changing relative prices into the analysis explicitly through a chain index, and this is what is done for RGDPCH. As we want to use growth figures over a longer period of time, it is thus best to use the growth figures of RGDPCH.

\section{Org_stat}

Year of origin of a statistical office.

\section{Gov_share}

Government share of CGDP from PWT 6.2. Averaged over 1994-2003.

See again Summers and Heston (1991) pg 343-344: as we do not compare countries over years, but only compare countries (so cross-section) using averages of variables over years, we can use this variable as a share of CGDP instead of as a share of RGDPL.

\section{Gov_share_ln}

Same as gov_share only now logarithms are taken and then the values are averaged over 1994-2003.

\section{Open_share}

Openness in current prices from PWT 6.2. Averaged over 1994-2003. This variable is Exports plus Imports divided by GDP and is the total trade as a percentage of GDP. Same reasoning as for Government share of CGDP.

\section{Open_share_ln}

Same as open_share only now logarithms are taken and then the values are averaged over 1994-2003.

\section{Price_inv}

Price level of investment from PWT 6.2. Averaged over 1994-2003.

\section{Price_inv_ln}

Same as price_inv only now logarithms are taken and then the values are averaged over 1994-2003. 


\section{Gr_pop}

Growth figures (100*(change in the natural logarithm)) of population from PWT 6.2 (which uses WDI). Averaged over 1994-2003.

\section{GDP_1993}

Real Gross Domestic Product per capita (CGDP) of 1993 from PWT 6.2.

Indicates initial wealth level. Same reasoning as for Government share of CGDP.

\section{GDP_1993_ln}

Logarithm of gdp_1993.

\section{Infl}

Inflation, consumer prices (annual \%) from GDNGD (not completely available for 2003, supplemented with WDI). Averaged over 1994-2003.

\section{Sec_school_1990}

Secondary school enrolment (\% gross) from WDI, which uses as source UNESCO. Year 1990, but for some countries the observation for this year is missing and therefore replaced by the year before or after 1990. If this is missing too, but an observation for 1988 or 1992 is available, this observation is used.

Gross enrolment ratio is the ratio of total enrolment, regardless of age, to the population of the age group that officially corresponds to the level of education shown.

\section{Pol_rights}

Political rights index from Freedom House, averaged over 1994-2003.

The index is a numerical rating between 1 and 7 for each country or territory, with 1 representing the most free and 7 the least free. Each pair of political rights and civil liberties (see next variable) ratings is averaged to determine an overall status of "Free," "Partly Free," or "Not Free.” Those whose ratings average 1.0 to 2.5 are considered Free, 3.0 to 5.0 Partly Free, and 5.5 to 7.0 Not Free 


\section{Civil lib}

Civil liberties index from Freedom House, averaged over 1994-2003.

The index is a numerical rating between 1 and 7 for each country or territory, with 1 representing the most free and 7 the least free. Each pair of political rights (see previous variable) and civil liberties ratings is averaged to determine an overall status of "Free," "Partly Free," or "Not Free." Those whose ratings average 1.0 to 2.5 are considered Free, 3.0 to 5.0 Partly Free, and 5.5 to 7.0 Not Free

\section{Gastil}

Average between pol_rights and civil_lib. 


\section{References}

Acemoglu, D., S. Johnson, J. Robinson and Y. Thaicharoen (2003), Institutional causes, macroeconomic symptoms: volatility, crises and growth, Journal of Monetary Economics, 50, 49-123.

Axelrod, R. (1984), The Evolution of Cooperation, New York: Basic Books,

Barro, R.J. (1991), Economic growth in a cross section of countries, Quarterly Journal of Economics, 106, 407-443.

Cuaresma, C.J. and G. Doppelhofer (2007), Nonlinearities in cross-country growth regressions: A Bayesian Averaging of Thresholds (BAT) approach, Journal of Macroeconomics, 29, 541-554.

Durlauf, S.N. and P.A. Johnson (1995), Multiple regimes and cross-country growth behaviour, Journal of Applied Econometrics, 10, 365-384.

Easterly, W. and R. Levine (1997), Africa’s growth tragedy: Policies and ethnic divisions, Quarterly Journal of Economics, 112, 1203-1250.

Kalaitzidakis, P., T.P. Mamuneas, and T. Stengos (2001), Measures of human capital and nonlinearities in economic growth, Journal of Economic Growth, 6, 229-254.

Lin, J.Y. and J.B. Nugent (1995), Institutions and economic development, in J. Behrman and T.N. Srinivasan (eds.), Handbook of Development Economics, Volume 3A, Amsterdam: North-Holland.

Nelson, R.R. and B.N. Sampat (2001), Making sense of institutions as a factor shaping economic performance, Journal of Economic Behaviour and Organisation, 44 (1), 31-54. 
North, D.C. (1990), Institutions, Institutional Change and Economic Performance, New York: Cambridge University Press.

North, D.C. (1994), Economic performance through time, American Economic Review, 84 (3), 359-368.

Summers, R. and A. Heston (1991), The Penn World Table (Mark 6.2): An expanded set of international comparisons, 1950-1988, Quarterly Journal of Economics, 106 (2), 327368.

Ugur, M. (2010), Institutions and economic performance: A review of the theory and evidence, Unpublished report, University of Greenwich Business School

Williamson, O.E. (1975), Markets and Hierarchies: Analysis and Antitrust Implications, New York: Free Press. 